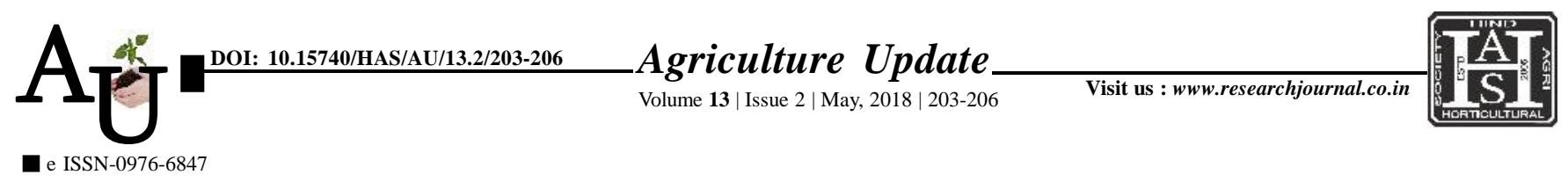

\title{
Rевекси автіск: e- Readiness and determinants of e-readiness of farmers - A study on the mobile based ICT users in agriculture
}

\author{
Q Ravinder Naik Vankudothu, Rabindra Nath Padaria and Sudheep Marwah
}

Article Chronicle: Received : 23.10.2017;

Revised : 04.04.2018; Accepted :

17.04.2018

KeY Words: e-readiness, Mobile advisory beneficiaries, Policy makers, Effective utilisation

Author for correspondence :

\section{Ravinder Naik} Vankudothu AICC and PJTSAU Press, Professor Jayashankar Telangana State Agricultural University, Rajendra Nagar, Hyderabad (Telangana) India Email:ravinaikiari2011@ gmail.com

See end of the article for authors' affiliations
SUMMARY : Information and Communication Technology (ICT) plays an important role in the transfer of agricultural information to the farming community. The benefits and reach of such ICT interventions amongst the farming community depend upon several factors such as e-readiness level and extent of utilisation of the ICT based extension services. The present study as part of Ph.D. research work was an attempt to measure the e-readiness level of the farmers of mobile based ICT users at the division of Agriculture Extension, IARI, New Delhi. Data were gathered from farmers (users and non users of ICT based extension service) from Andhra Pradesh, Telangana, Madhya Pradesh and Karnataka states of India. Majority of the mobile advisory beneficiaries (95\%) were less e-ready. Variables namely Zaid crops, innovativeness and risk orientation showed significant and positive effect on e-readiness of the farmers while age showed significantly negative effect on e-readiness. The findings of the study related to e-readiness level of the farmers could provide guidance to the relevant organisations and policy makers for designing and implementation of ICT programmes for the effective utilisation of ICT based extension projects.

How to cite this article : Vankudothu, Ravinder Naik, Padaria, Rabindra Nath and Marwah, Sudheep (2018). eReadiness and determinants of e-readiness of farmers - A study on the mobile based ICT users in agriculture. Agric. Update, 13(2): 203-206; DOI : 10.15740/HAS/AU/13.2/203-206. Copyright@ 2018: Hind Agri-Horticultural Society. 